\title{
Effects of masks, social distancing and general hygiene recommendations on rotavirus gastroenteritis in children during the COVID-19 pandemic
}

\section{COVID-19 pandemisindeki maske, sosyal mesafe ve genel hijyen önerilerinin çocuklardaki rotavirüs gastroenteriti üzerindeki etkileri}

\author{
Eren Yıldız ${ }^{1}$,Zübeyde Dinçer ${ }^{2}$, Mehmet Ali Narsat ${ }^{3}$,Emrah Çı̆̆rı ${ }^{1}$, Funda Çatan İnan ${ }^{4}$
}

\begin{abstract}
Aim: Acute gastroenteritis (AGE) is one of the important causes of mortality and morbidity for children worldwide, especially in developing countries. Rotavirus is transmitted by the feces of the people carrying it through food and hands. Additionally, door handles, telephones, sockets, and toys may play a role in spreading the infection. In addition to fecal-oral transmission, transmission via droplets has also been reported. In this study, we aimed to evaluate the frequency and characteristics of rotavirus in pediatric acute gastroenteritis cases in our institution and reveal the effect of the increased mask, social distancing and general hygiene recommendations with COVID-19 pandemic on rotavirus gastroenteritis. Methods: A total of 4781 patients aged 0-18 diagnosed with AGE between January 2019 and December 2020 were included in the study. The rotavirus positivity of patients diagnosed with acute gastroenteritis before and after the pandemic was statistically compared according to season, gender, and age variables. Results: Four hundred nine (8.6\%) of 4781 patients were determined as rotavirus positive. The frequency of rotavirus in the age range of 0-2 was higher than that of in the other age ranges. Rotavirus is more common in the winter and spring seasons. In the modeling performed for patients with AGE in our hospital, provided that the other variables remained constant, the risk of rotavirus positivity increased by 1.14 times with the season variable while it decreased by 0.66 times with age. It was concluded that as the age increased, the odds value of being rotavirus positive decreased by $33.4 \%$. While the prevalence of rotavirus gastroenteritis was $7.5 \%$ between March 2019 and December 2019 , this frequency decreased to $4.7 \%$ with the pandemic (March 2020-December 2020), which was statistically significant $\left(X^{2}=8.620\right.$; $p=0.003$ ). Conclusion: Increasing masks, social distancing and general hygiene recommendations due to COVID 19 have led to a decrease in the frequency of rotavirus infections in children.
\end{abstract}

Keywords: Children, COVID-19, distancing, hygiene, masks, rotavirus

\section{ÖZET}

Amaç: Akut gastroenterit (AGE) gelişmekte olan ülkeler bașta olmak üzere tüm dünyada çocuklar için önemli mortalite ve morbidite nedenlerinden biridir. Rotavirüs; taşıyan kişinin dışkısıyla yiyecekler ve eller aracılığıyla bulaşırken kapı kolları, telefonlar, yuvalar, oyuncaklar da enfeksiyonun yayılmasında rol oynayabilir. Fekal-oral bulaşın yanında damlacık yoluyla bulaşma da bildirilmiştir. Çalışmamızda; kurumumuzdaki çocuk AGE olgularında rotavirüs sıklığının ve özelliklerinin değerlendirilmesi ve COVID-19 pandemisi ile artmış maske, mesafe ve genel hijyen önerilerinin rotavirüs gastroenteritlerine etkisinin ortaya koyulması amaçlanmıştır. Yöntem: Ocak 2019 ile Aralık 2020 tarihleri arasında akut gastroenterit tanısı ile değerlendirilen 0-18 yas aralığındaki 4781 hasta çalışmaya dahil edilmiştir. Araştırmada, pandemi öncesi ve sonrası dönemdeki akut gastroenterit tanılı hastaların mevsim, cinsiyet ve yaş değişkenlerine göre rotavirüs pozitiflik durumları istatistiksel olarak karşılaştırılacaktır. Bulgular: Rotavirüs pozitifliği 4781 hastanın 409’unda (\%8.6) tespit edilmiştir. Rotavirüs görülme sıklığı 0-2 yaş aralığında, diğer yaş aralığındaki çocuklara göre daha yoğundur. Kış ve ilkbahar mevsimlerinde de rotavirüs daha çok görülmektedir. Hastanemiz akut gastroenterit olguları için yapılan modellemede rotavirüs pozitifliği riskini diğer değișenler sabit kalması koșuluyla mevsim değişkeni 1,14 kat arttırırken, yaş 0,66 kat azaltmaktadır. Yaş arttıkça rotavirüs pozitifli odds değerinin de \%33,4 azalış gösterdiği sonucuna ulaşılmıştır. Mart 2019 - Aralık 2019 döneminde rotavirüs gastroenteritinin görülme sıklı̆̆ $1 \% 7,5$ iken, pandeminin başlangıcı ile birlikte (Mart 2020- Aralık 2020 dönemi) bu sıklık \%4,7’e düşmüştür, bu düşüş istatistiksel anlamlı olarak anlamlı saptanmıştır $\left(X^{2}=8,620 ; p=0,003\right)$. Sonuç: COVID 19 nedeniyle artan maske, sosyal mesafe ve genel hijyen önerileri, çocuklarda rotavirüs enfeksiyonu sıklığının azalmasına neden olmuştur.

Anahtar kelimeler: Çocuklar, COVID-19, mesafe, hijyen, maske, rotavirüs

Received / Geliș tarihi: 06.05.2021, Accepted / Kabul tarihi: 22.06.2021

1 Kastamonu University Faculty of Medicine, Department of Pediatrics, Kastamonu, Turkey

2 Kastamonu Training and Research Hospital, Department of Pediatrics, Kastamonu, Turkey

3 Kastamonu Training and Research Hospital, Department of Pediatric Surgery, Kastamonu, Turkey

4 Kastamonu University Faculty of Medicine, Department of Biostatistics, Kastamonu, Turkey

*Address for Correspondence / Yazışma Adresi: Eren Yıldız, Kastamonu University Faculty of Medicine, Department of Pediatrics, Kastamonu, Turkey.

E mail: eren70@gmail.com

Yıldız E, Dinçer Z, Narsat MA, Çığrı E, Çatan İnan F. Effects of masks, social distancing and general hygiene recommendations on rotavirus gastroenteritis in children during the COVID-19 pandemic. TJFMPC, 2021;15(3): 546-551.

DOI: $10.21763 /$ tjfmpc.933726 


\section{INTRODUCTION}

Acute gastroenteritis (AGE) is one of the major causes of mortality and morbidity for children all over the world, especially in developing countries. AGE agents can be viral, bacterial, parasitic or fungal. ${ }^{1}$ Frequently, it is transmitted via the fecaloral route through the droplet related to water sources, sewage systems, and personal hygiene. Rotavirus takes first place among viral gastroenteritis agents. ${ }^{2}$ It causes serious fluid loss from the body by affecting the small intestines and disrupting fluid and electrolyte absorption. Although it is common in the winter months (DecemberJanuary), rotavirus gastroenteritis can be seen in all periods of the year. Although it can be seen at any age, it generally affects children between 4-24 months. The rotavirus is transmitted by the feces of the people carrying it through food and hands. Additionally, door handles, telephones, sockets, and toys may also play a role in spreading the infection. The incubation period of the disease is 1-3 days. At the end of this period, a mild fever occurs, often accompanied by vomiting. Patients present to the hospital with three or more complaints of diarrhea, vomiting or fever, nausea, and abdominal pain caused by gastrointestinal inflammation. ${ }^{3,4}$

In early December 2019, an unknown series of pneumonia cases emerged in China. ${ }^{5}$ A new type of coronavirus that was not previously detected in humans was isolated in bronchoalveolar lavage fluids taken from these patients. The disease which was caused by the 2019-nCoV or SARS-CoV-2 virus was accepted as COVID-19 by the World Health Organization (WHO). ${ }^{6}$ With the COVID-19 pandemic, increasing contact isolation measures have decreased infections, which can be seen from influenza data. ${ }^{7}$ Not surprisingly, a similar effect is expected to occur in all other infectious agents. It is also expected that the frequency and effects of a factor that is transmitted via fecal-oral and droplet such as rotavirus will decrease with increased hygiene habits. In addition, the presence of diarrhea identified in the gastrointestinal involvement of COVID-19 may be overlooked; that is, there may be the presence of SARS-CoV-2, a new viral agent that reduces the frequency of rotavirus. ${ }^{8}$

In our study, we evaluated the frequency and characteristics of rotavirus in pediatric AGE cases in our institution, the only tertiary hospital of our city in which $41.9 \%$ of the population still live in villages and rural areas. Additionally, we aimed to reveal the effect of increased masks, distancing, and general hygiene recommendations on rotavirus gastroenteritis with the COVID-19 pandemic, which started to appear in our country in March 2020.

\section{MATERIAL AND METHOD}

A total of 4781 patients aged 0-18 who were diagnosed with AGE between January 2019 and December 2020 in Kastamonu Training and Research Hospital were included in the study. Local ethical committee approval was obtained (Date: 28.01.2021, No:2020-KAEK-143-27). The presence of rotavirus antigen in the stool samples of the patients was retrospectively analyzed. In this evaluation, the "Toyo in vitro diagnostic test (İzmir, Turkey)" kit, which is a rapid, immunochromatographic one-step test used for the qualitative detection of rotavirus antigens, was used. While this test was being studied, the manufacturer's recommendations were taken as basis. In the study, the rotavirus positivity of patients diagnosed with acute gastroenteritis before and after the pandemic was statistically compared according to season, gender, and age variables.

SPSS-23 program was used to analyze the data. Pearson's chi-square tests were used in the comparison of categorical variables, which were compatible with statistical assumptions. Frequency and percentage values were calculated for categorical data as descriptive statistics. Factors affecting rotavirus positivity were determined by using the enter method using binary logistic regression analysis. In the analysis, 1 indicates the presence of rotavirus while 0 indicates the absence of rotavirus. The independent variables that are thought to affect the presence of rotavirus and added to the model are age, season, and year variables. Parameter estimates affecting rotavirus positivity in the logistic regression analysis as well as standard errors, Wald statistics, degrees of freedom, odds ratios, and confidence limits are given in Table 2 . In the evaluation of the tests, $p<0.05$ was considered statistically significant.

\section{RESULTS}

Among the 4781 patients included in the study, 409 $(8.6 \%)$ were identified as rotavirus positive. Table 1 examines the frequency of rotavirus in terms of gender, age groups, season, and treatment method. According to the Chi-Square analysis, while the frequency of rotavirus in terms of gender did not show a significant difference $\left(X^{2}=0.850 ; p=0.360\right)$, there was a significant difference between the other variables $(\mathrm{p}<0.001)$. Accordingly, the frequency of rotavirus in the $0-2$ age range was higher than in children in the other age range. Rotavirus is more common in the winter and spring seasons. Patients are mostly followed up on an outpatient basis. 
Table 1. Frequencies of several variables among studied participants by rotavirus

\begin{tabular}{|c|c|c|c|c|c|c|c|}
\hline \multicolumn{8}{|c|}{ Rotavirus } \\
\hline & & \multicolumn{2}{|c|}{ Negative } & \multicolumn{2}{|c|}{ Positive } & \multirow[b]{2}{*}{$\mathbf{X}^{2}$} & \multirow[b]{2}{*}{$\mathbf{p}$} \\
\hline & & $\mathbf{n}$ & $\%$ & $\mathbf{n}$ & $\%$ & & \\
\hline \multirow{2}{*}{ Gender } & Female & 1917 & 43.8 & 189 & 46.2 & \multirow{2}{*}{0.850} & \multirow{2}{*}{0.360} \\
\hline & Male & 2455 & 56.2 & 220 & 53.8 & & \\
\hline \multirow{3}{*}{ Age groups } & $0-2$ age & 1677 & 38.4 & 215 & 52.6 & \multirow{3}{*}{51.27} & \multirow{3}{*}{$<0.001$} \\
\hline & 3-5 age & 841 & 19.2 & 94 & 23 & & \\
\hline & 5-18 age & 1854 & 42.4 & 100 & 24.4 & & \\
\hline \multirow{4}{*}{ Season } & Spring & 971 & 22.2 & 133 & 32.5 & \multirow{4}{*}{145.87} & \multirow{4}{*}{$<0.001$} \\
\hline & Summer & 1347 & 30.8 & 55 & 13.5 & & \\
\hline & Autumn & 988 & 22.6 & 38 & 9.3 & & \\
\hline & Winter & 1066 & 24.4 & 183 & 44.7 & & \\
\hline \multirow{2}{*}{ Treatment } & Outpatient & 3982 & 91.1 & 305 & 74.6 & \multirow{2}{*}{110.00} & \multirow{2}{*}{$<0.001$} \\
\hline & Hospitalized & 390 & 8.9 & 104 & 25.4 & & \\
\hline
\end{tabular}

Pearson's Chi-Square test, $\mathrm{p}<0.05$

The distribution of the mean rotavirus positivity percentages of the patients included in the study for 2019 and 2020 in addition to the general condition by months is shown in Figure 1. In all cases, the rate of rotavirus in January, February and March was higher than that of in other months. While this value peaked in February for 2019, it reached the peak in March for 2020.

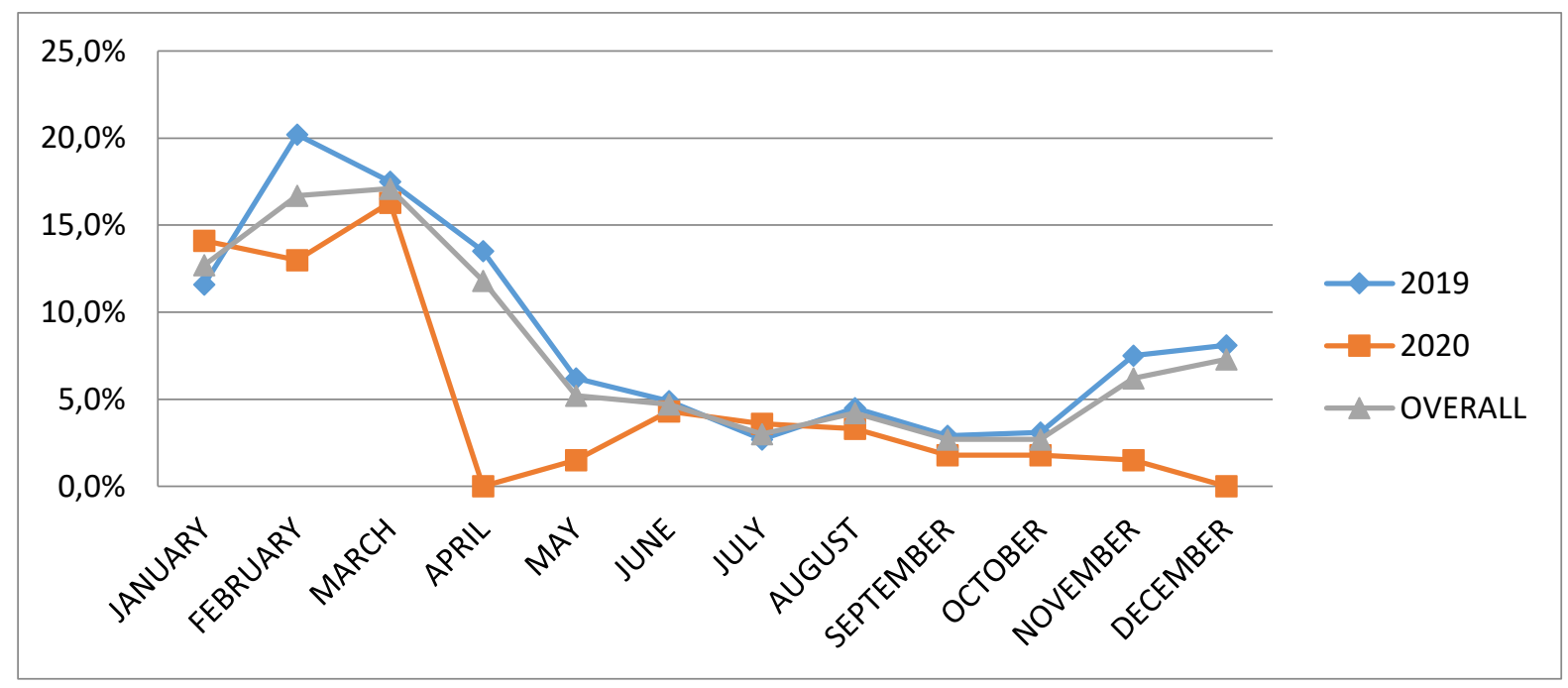

Figure 1. Distribution of rotavirus positivity by months 
According to the results of the binary logistic regression, it was seen that season and age variables had an effect on rotavirus positivity and were risk factors in determining rotavirus positivity. With the Hosmer-Lemeshow test conducted to test the significance of the model, it was concluded that the model fit was quite good and the parameters had good discrimination in terms of determinism. In the modeling performed for patients with AGE in our hospital, the risk of rotavirus positivity provided that the other variables remained constant, increased 1.14 times by the season variable that had summer as reference season, it decreased 0.66 times by age. It was concluded that as the age increased, the odds value of being rotavirus positive decreased by $33.4 \%$ (Table 2).

Table 2. Binary logistic regression analysis for predictors of rotavirus positivity

\begin{tabular}{lccccccc}
\hline & B & S.E. & Wald & Sig & $\operatorname{Exp}(\mathbf{B})$ & \multicolumn{2}{c}{ \%95 Confidence Interval } \\
\cline { 6 - 8 } & & & & & & Lower & Upper \\
\hline Constant & -1.94 & 0.17 & 126.60 & $<0.001$ & 0.14 & & 1.25 \\
Age & 0.12 & 0.05 & 7.62 & 0.006 & 1.14 & 1.04 & 0.75 \\
\hline
\end{tabular}

Binary logistic regression analysis with enter method, $\mathrm{p}<0.05$

The number of patients diagnosed with AGE decreased during the pandemic. In addition, the incidence of rotavirus gastroenteritis was $7.5 \%$ in the period between March 2019 and December 2019, which we consider as the pre-pandemic period. This frequency decreased to $4.7 \%$ with the onset of the pandemic (March 2020-December 2020 period), which was significantly significant $\left(X^{2}=8.620\right.$; $\mathrm{p}=0.003$ ) (Table 3 ). Mortality did not develop in any of the patients included in the study.

\begin{tabular}{|c|c|c|c|c|c|c|}
\hline & \multicolumn{4}{|c|}{ Rotavirus } & \multirow[b]{3}{*}{$\mathbf{X}^{2}$} & \multirow[b]{3}{*}{$\mathbf{p}$} \\
\hline & \multicolumn{2}{|c|}{ Negative } & \multicolumn{2}{|c|}{ Positive } & & \\
\hline & $\mathbf{n}$ & $(\%)$ & $\mathbf{n}$ & $(\%)$ & & \\
\hline March-December 2019 & 2654 & $(\% 92.5)$ & 214 & $(\% 7.5)$ & \multirow{2}{*}{8.620} & \multirow{2}{*}{0.003} \\
\hline March-December 2020 & 911 & $(\% 95.3)$ & 45 & $(\% 4.7)$ & & \\
\hline
\end{tabular}

Pearson's Chi-Square test, $\mathrm{p}<0.05$

\section{DISCUSSION}

In our study, there was a significant decrease in the total number of AGE patients and the number of patients with rotavirus gastroenteritis during the pandemic period. Another important point is that the rate of AGE due to rotavirus decreased more according to the total number of patients. This extra change may have been caused by multiple reasons. 
We think that this decrease is due to the fact that masks, social distancing and general hygiene recommendations reduce transmission in children during the COVID-19 pandemic. Besides, COVID19, which is known to have gastrointestinal involvement, may also be one of the causes of diarrhea. ${ }^{8}$ We predict that the SARS-CoV-2 virus, previously thought as a respiratory system pathogen, may have replaced rotavirus diarrhea in some of our pediatric patients due to its prevalence in the society. This hypothesis needs to be supported by SARSCov-2 screening in patients diagnosed with gastroenteritis.

AGE continues to be an important health problem, especially in rural areas and developing countries. ${ }^{1,9}$ Difficulties in accessing clean water resources and the lack of hygiene are the most important factors affecting the frequency of AGEs. ${ }^{1,10}$ AGEs due to rotavirus can still be fatal in some regions; these cases can be lost due to dehydration and insufficient supportive treatment. The fact that there was no mortality and morbidity in nearly 5000 AGE patients during this study is consistent with other studies conducted in our country. ${ }^{11}$

The AGE and rotavirus characteristics of our region are compatible with other studies conducted in our country. ${ }^{12}$ As seen in the literature, the 0 -2 age group is the age group with the highest admission to the hospital with AGE. ${ }^{12}$ It is observed that there is no gender difference and the frequency of AGE patients due to rotavirus increases in the winter months. In addition to its viral properties, it is thought that this increase may be caused by the contamination of the domestic water due to rains in the winter months. In the study of İlktaç et al, seasonal characteristics are in a similar distribution with our study. In our study, in which rotavirus positivity was intense between December and May, a similar distribution was observed, and this positivity peaked in February. ${ }^{12}$

Seasonal characteristics and age appear to be acceptable predictors of rotavirus positivity in AGE patients in our study. It is seen that the risk of AGE factor becoming rotavirus reduced by 0.66 times with growth. It can be argued that this proportional value for rotavirus diarrhea, which is known to be more common in younger children, is a new perspective that our study has brought to the literature.

Although the measures taken for COVID-19 affect several aspects of life and bring many difficulties, studies have shown that the incidence of many other infectious diseases has decreased thanks to the lifestyle change it brings. ${ }^{7,13,14}$ In the period of COVID-19 pandemic, more attention has been paid to social distancing, hygiene recommendations and mask use. Like influenza studies in the literature, this effect was demonstrated in terms of AGEs in our study. ${ }^{13,14}$

The burden and frequency of disease caused by rotavirus gastroenteritis can be prevented by rotavirus vaccines. The World Health Organization recommends the inclusion of rotavirus vaccines in all national immunization programs. ${ }^{15}$ Although not in the routine national scheme in our country, this vaccine can be supplied on demand. The effects of the proliferation of rotavirus vaccine have been observed in many countries. For instance, with the widespread use of the vaccine in the United States, a significant decrease was observed in hospitalization rates in rotavirus gastroenteritis. In Mexico, a significant decrease was observed in child mortality due to acute gastroenteritis, which was associated with the spread of vaccination. ${ }^{15} \mathrm{We}$ think that with the widespread use of vaccination, the severity and prevalence of rotavirus gastroenteritis will decrease further.

Our study has some limitations due to its being retrospective and single-centered. In addition, the fact that the exact causes of diarrhea could not be evaluated in about 4300 patients may have caused the change not to be fully demonstrated. COVID-19 PCR was not studied from these patients, which may have affected the results of the study. However, we think that our study is sufficient to bring this view into the literature and to recommend the evaluation of COVID-19 in these patients in future studies.

\section{CONCLUSION}

Increasing hygiene habits has decreased the number of AGEs and the frequency of rotavirus gastroenteritis. However, the factor in the greater reduction in the number of AGEs due to rotavirus may be the presence of overlooked SARS-CoV-2 as well as changing hygiene habits. More extensive research regarding this subject is needed. It should be considered that attention to hygiene rules following the COVID-19 pandemic is also important in terms of other infectious diseases.

\section{KAYNAKLAR}

1. Hartman S, Brown E, Loomis E, Russell HA. Gastroenteritis in Children [published correction appears in Am Fam Physician. 2019 Jun 15;99(12):732]. Am Fam Physician. 2019;99(3):159-165.

2. Oğuz S, Kurt F, Tekin D, Kocabaş BA, İnce E, Suskan E. Çocuk Acil Servisinde Rotavirus Gastroenteritlerinin Yükü J. Pediatr Inf 2014; 8: 99-104. 
3. Freedman SB, Thull-Freedman JD, Rumantir M, Atenafu EG, Stephens D. Emergency department revisits in children with gastroenteritis. J Pediatr Gastroenterol Nutr. 2013; 57(5):612-8.

4. Fox J, Richards S, Jenkins HR, Powell C. Management of gastroenteritis over 10 years: changing culture and maintaining the change. Arch Dis Child. 2012; 97(5):415-7.

5. Wang C, Horby PW, Hayden FG, Gao GF. A novel coronavirus outbreak of global health concern. Lancet. 2020;395:470-473.

6. Zhu N, Zhang D, Wang W, Li X, Yang B, Song J, Zhao X, Huang B, Shi W, Lu R, Niu P, Zhan F, Ma X, Wang D, Xu W, Wu G, Gao GF, Tan W China Novel Coronavirus Investigating and Research Team. A Novel Coronavirus from Patients with Pneumonia in China, 2019. N Engl J Med. 2020;382:727-733.

7. Nowak MD, Sordillo EM, Gitman MR, Paniz Mondolfi AE. Coinfection in SARS-CoV-2 infected patients: Where are influenza virus and rhinovirus/enterovirus?. J Med Virol. 2020;92(10):1699-

1700.doi:10.1002/jmv.25953

8. D'Amico F, Baumgart DC, Danese S, PeyrinBiroulet L. Diarrhea During COVID-19 Infection: Pathogenesis, Epidemiology, Prevention, and Management. Clin Gastroenterol Hepatol. 2020;18(8):1663-1672. doi:10.1016/j.cgh.2020.04.001

9. Badur S, Öztürk S, Pereira P, et al. Systematic review of the rotavirus infection burden in the WHO-EMRO region. Hum Vaccin Immunother. $\quad 2019 ; 15(11): 2754-2768$. doi: $10.1080 / 21645515.2019 .1603984$

10. Ahmed J, Wong LP, Chua YP, et al. Quantitative Microbial Risk Assessment of Drinking Water Quality to Predict the Risk of Waterborne Diseases in Primary-School Children. Int J Environ Res Public Health. 2020;17(8):2774. Published 2020 Apr 17. doi:10.3390/ijerph17082774

11. Tapisiz A, Bedir Demirdag T, Cura Yayla BC, et al. Rotavirus infections in children in Turkey: A systematic review. Rev Med Virol. 2019; 29:e2020. https://doi.org/10.1002/rmv.2020

12. İlktaç $M$, Şahin $A$, Nazik $H$, et al. Akut Gastroenteritli Çocuklarda Rotavirus Sıklığının
Araştırılması ve Rotavirus Sezonunun Takibi: Beş Yıllık Sonuçların Değerlendirilmesi. Ankem Derg, 2012, 26.1: 25-29.

13. Wu D, Lu J, Sun Z, et al. Rhinovirus remains prevalent in school teenagers during fight against COVID-19 pandemic. Immun Inflamm Dis. 2021;9(1):76-79. doi:10.1002/iid3.381

14. Pinky L, Dobrovolny HM. SARS-CoV-2 coinfections: Could influenza and the common cold be beneficial?. J Med Virol. 2020;92(11):2623-2630. doi:10.1002/jmv.26098

15. Rotavirus.https://www.who.int/immunization/d iseases/rotavirus/en (accessed: 10.05.2021). 